\title{
Marine benthic algal flora of Ascension Island, South Atlantic
}

\author{
KONSTANTINOS TSIAMIS ${ }^{1}$, AKIRA F. PETERS ${ }^{2}$, DAWN M. SHEWRING ${ }^{3}$, ALDO O. ASENSI ${ }^{4}$, \\ PIETER VAN WEST ${ }^{5}$ AND FRITHJOF C. KÜPPER ${ }^{3}$ \\ ${ }^{1}$ Hellenic Centre for Marine Research (HCMR), Institute of Oceanography, Anavyssos 19013 Attica, Greece, ${ }^{2}$ Bezhin Rosko, 40 rue \\ des pêcheurs, 29250 Santec, Brittany, France, ${ }^{3}$ Oceanlab, University of Aberdeen, Main Street, Newburgh AB41 6AA, UK, ${ }^{4} 15$ rue \\ Lamblardie, F-75012 Paris, France, ${ }^{5}$ Aberdeen Oomycete Laboratory, University of Aberdeen, Institute of Medical Sciences, \\ Foresterhill, Aberdeen AB25 2ZD, UK
}

\begin{abstract}
This paper provides a comprehensive checklist of the marine benthic macroalgal flora of Ascension Island (tropical South Atlantic Ocean), based on both new collections and previous literature. 82 marine macroalgae were identified from our work, including 18 green algae (Ulvophyceae), 15 brown algae (Phaeophyceae) and 49 red algae (Rhodophyta). Among our collections, 38 species and infraspecific taxa are reported for the first time from Ascension Island, including seven green, three brown and 28 red macroalgae, raising the total number of seaweeds recorded in Ascension so far to 112 taxa in species and infraspecific level. No seagrasses have been recorded at Ascension Island.
\end{abstract}

Keywords: algae, seagrasses, checklist, seaweeds, marine vegetation

Submitted 12 April 2014; accepted 18 June 2014; first published online 27 August 2014

\section{INTRDDUCTION}

Ascension Island is one of the remotest volcanic islands worldwide, located $07^{\circ} 57^{\prime}$ south of the Equator, near the Mid-Atlantic Ridge, about $1600 \mathrm{~km}$ from West Africa and $2400 \mathrm{~km}$ from South America. St Helena Island is the nearest island to Ascension, about $1130 \mathrm{~km}$ to the south-east.

The coastline of Ascension varies, ranging from sea cliffs and steep slopes (mainly eastern coasts) to sandy beaches and smooth sublittoral areas and rocky beaches (mainly western coasts), thus creating several different types of coastal habitats for various seaweed communities (Price \& John, 1980). However, the most important factor governing seaweed development in Ascension is the presence of the marauding blackfish (Melichthys niger Bloch, 1786), the most dominant fish species around the coast and seemingly mainly responsible for the paucity of the island's benthic algal flora (Price \& John, 1979, 1980).

Only a few studies regarding the marine seaweed flora of Ascension Island have been carried out previously. Osbeck $(1757,1765,1771)$ was the first to report marine algae from Ascension, based on drift specimens. In the 19th Century sparse records were provided by Bory (1829) and Askenasy (1888), while about a century later a single green seaweed (Valonia sp.) was reported from the inland saline pools of the island (Chace \& Manning, 1972). Finally, a more detailed survey of Ascension's seaweeds was performed in October and November 1976 by Price \& John (1979, 1980). Taking into account their original work, additional records from Ascension Island were included in the series of 'Seaweeds of

Corresponding author:

F.C. Küpper

Email: fkuepper@abdn.ac.uk the western coast of tropical Africa and adjacent islands: a critical assessment' (Lawson \& Price, 1969; Price et al., 1978, 1986, 1988, 1992; John et al., 1979, 1994; Lawson et al., 1995; Woelkerling et al., 1998) as well as in the updated catalogue of seaweeds of the western coast of Africa and adjacent islands (John et al., 2004)

After 36 years since the seaweed collections of Price \& John (1980) at Ascension shores, we conducted an extensive seaweed survey in the island's coastal environment, aiming to update the knowledge about Ascension marine benthic macroalgal flora. Older records from the island are also covered, providing a comprehensive check list of the marine seaweeds of Ascension Island.

\section{MATERIALS AND METHDDS}

The seaweed flora of Ascension Island was investigated during a one-week period in February 2011 and a two-and-a-halfweek period in September 2012. Several rocky sites were chosen along the island's shores (Table 1), from the eulittoral zone down to $38 \mathrm{~m}$ depth. Similar to previous work by Price \& John (1980) we sampled seaweeds in various types of coastal habitat: rock pools (Catherine Point, Collyer Point, Shelly Beach, Wideawake Plains); blow-hole areas (Catherine Point); turtle ponds (Georgetown); midlittoral rocks and beach rocks (Pillar Bay, Collyer Point, Clarkes Beach); the outfall channel from the island's main power station (Derby wreck); and sublittoral rocks (English Bay, Comfortless Cove, Sudan wreck site, Derby wreck site, Horseshoe Reef, Red Rock Cave, and a sublittoral reef west of Georgetown).

Seaweeds were collected by snorkelling and SCUBA-diving through the destructive method (scraping the macroalgae off the substratum). Underwater photographs were taken using 
Table 1. Seaweed taxa recorded in inshore waters of Ascension Island, based both on our collections and previous known literature. Taxa are listed alphabetically for each group (Ulvophyceae, Phaeophyceae and Rhodophyta), in order to make their detection easier. Synonyms used in previous publications are also given. Superscript numbers in taxa refer to notes. The exact location where each taxon was collected during our samplings as well as habitat details are provided (1, Catherine Point; 2, Clarkes Beach; 3, Collyer Point; 4, Comfortless Cove; 5, Derby wreck (in English Bay); 6, English Bay; 7, Georgetown; 8, Horseshoe Reef; 9, Pillar Bay; 10, Red Rock Cave; 11, Shelly Beach; 12, Sublittoral reef west of Georgetown; 13, Sudan wreck; 14, Wideawake Plains).

\begin{tabular}{|c|c|c|c|}
\hline & $\begin{array}{l}\text { Location } \\
\text { found }\end{array}$ & Habitat & Previous records \\
\hline \multicolumn{4}{|l|}{ ULVOPHYCEAE } \\
\hline Bryopsis duplex De Notaris & 4 & Upper sublittoral rocks & \\
\hline Bryopsis plumosa (Hudson) C. Agardh & 5,6 & Upper sublittoral rocks & \\
\hline $\begin{array}{l}\text { Caulerpella ambigua (Okamura) Prud'homme van Reine \& } \\
\text { Lokhorst = Caulerpa vickersiae Børgesen }\end{array}$ & 3 & Beach rock & Price \& John (1980) \\
\hline Chaetomorpha aerea (Dillwyn) Kützing & & & John et al. (2004) \\
\hline Chaetomorpha antennina (Bory de Saint-Vincent) Kützing & 3,7 & Turtle Ponds, midlittoral rocks & Price \& John (1980) \\
\hline Cladophora coelothrix Kützing & & & Price \& John (1980) \\
\hline Cladophora corallicola Børgesen & 13 & Sublittoral rocks & \\
\hline Cladophora hutchinsiae (Dillwyn) Kützing & 7 & Turtle ponds & \\
\hline Cladophora laetevirens (Dillwyn) Kützing & 5 & Outfall channel & \\
\hline Cladophora lehmanniana (Lindenberg) Kützing & 4,5 & Upper sublittoral rocks & \\
\hline Codium taylorii P.C. Silva & 1,3 & Blow-hole areas, rock pools & Price \& John (1980) \\
\hline Dictyosphaeria versluysii Weber-van Bosse & 1 & Rock pools & Price \& John (1980) \\
\hline Neomeris annulata Dickie & 4 & Sublittoral rocks & Price \& John (1980) \\
\hline $\begin{array}{l}\text { Phyllodictyon anastomosans (Harvey) Kraft \& M.J. Wynne }= \\
\text { Struvea anastomosans (Harvey) Piccone \& Grunow ex Piccone }\end{array}$ & 6,12 & Sublittoral rocks & Price \& John (1980) \\
\hline Rhizoclonium riparium (Roth) Harvey & & & John et al. (2004) \\
\hline Ulva clathrata (Roth) C. Agardh & 5 & Outfall channel, substratum culture & John et al. (2004) \\
\hline Ulva compressa Linnaeus & & & Lawson \& Price (1969) \\
\hline $\begin{array}{l}\text { Ulva flexuosa Wulfen }=\text { Enteromorpha flexuosa } \text { (Wulfen) } \\
\text { J. Agardh }=\text { E. lingulata J. Agardh }\end{array}$ & 3 & Rock pools & Price \& John (1980) \\
\hline $\begin{array}{l}\text { Ulva intestinalis Linnaeus = Enteromorpha intestinalis (Linnaeus) } \\
\text { Nees }\end{array}$ & 5 & Outfall channel & Price \& John (1980) \\
\hline Ulva lactuca Linnaeus & & & Price \& John (1980) \\
\hline Ulvella leptochaete (Huber) R. Nielsen, C.J.O’ Kelly \& B. Wysor & 6 & $\begin{array}{l}\text { Appeared in raw culture of filamentous } \\
\text { brown alga }\end{array}$ & \\
\hline Valonia macrophysa Kützing & 3,6 & Rock pools, sublittoral rocks & John et al. (2004) \\
\hline $\begin{array}{l}\text { Valonia ventricosa J. Agardh = Ventricaria ventricosa }(\mathrm{J} . \text { Agardh }) \\
\text { J.L. Olsen \& J.A. West }\end{array}$ & 3,11 & Rock pools & Price \& John (1980) \\
\hline \multicolumn{4}{|l|}{ PHAEOPHYCEAE } \\
\hline $\begin{array}{l}\text { Asteronema breviarticulatum (J. Agardh) Ouriques \& Bouzon = } \\
\text { Ectocarpus breviarticulatus J. Agardh }\end{array}$ & 3,9 & $\begin{array}{l}\text { Midlittoral rocks and beach rock, } \\
\text { rock pools }\end{array}$ & Price \& John (1980) \\
\hline Bachelotia antillarum (Grunow) Gerloff & 3,7 & Turtle ponds, midlittoral rocks & Price \& John (1980) \\
\hline Chnoospora minima (Hering) Papenfuss & $1,3,14$ & $\begin{array}{l}\text { Blow-hole areas, midlittoral rocks, } \\
\text { rock pools }\end{array}$ & Price \& John (1980) \\
\hline Colpomenia sinuosa (Mertens) Derbès \& Solier & 1,3 & Blow-hole areas, rock pools & Price \& John (1980) \\
\hline $\begin{array}{l}\text { Dictyota bartayresiana J.V. Lamouroux = Dictyota bartayresii J.V. } \\
\text { Lamouroux }\end{array}$ & 1,4 & Rock pools, sublittoral rocks & Price \& John (1980) \\
\hline Feldmannia irregularis (Kützing) Hamel & 3 & Rock pools & \\
\hline Feldmannia paradoxa (Montagne) Hamel & 3 & Rock pools & \\
\hline $\begin{array}{l}\text { Feldmannia mitchelliae (Harvey) H.-S. Kim = Giffordia mitchelliae } \\
\text { (Harvey) Hamel = Hincksia mitchelliae (Harvey) P.C. Silva }\end{array}$ & 3,7 & Turtle ponds, rock pools & $\begin{array}{l}\text { Price \& John (1980); } \\
\quad \text { John et al. (2004) }\end{array}$ \\
\hline Levringia brasiliensis (Montagne) A.B. Joly & $1,3,14$ & Blow-hole areas, beach rock, rock pools & \\
\hline Levringia sordida (Bory de Saint-Vincent) Kylin & & & Price \& John (1980) \\
\hline Lobophora variegata (J.V. Lamouroux) Womersley ex E.C. Oliveira & 6 & Sublittoral rocks & Price \& John (1980) \\
\hline $\begin{array}{l}\text { Neoralfsia expansa (J. Agardh) Cormaci \& G. Furnari = Ralfsia } \\
\text { expansa (J. Agardh) J. Agardh }\end{array}$ & 1,3 & Blow-hole areas, rock pools & Price \& John (1980) \\
\hline Padina gymnospora (Kützing) Sonder = Padina vickersiae Hoyt & 1,3 & Blow-hole areas, rock pools & Price \& John (1980) \\
\hline Padina pavonica (Linnaeus) Thivy & & & John et al. (2004) \\
\hline $\begin{array}{l}\text { Sargassum lendigerum (Linnaeus) C. Agardh }{ }^{\mathrm{a}}=\text { Fucus lendigerum } \\
\text { Linnaeus }\end{array}$ & & & Linnaeus (1753) \\
\hline Sargassum vulgare C. Agardh (nom. illeg.) & 1,3 & Beach rock, rock pools & Price \& John (1980) \\
\hline Sphacelaria novae-hollandiae Sonder & $1,3,9$ & Midlittoral rocks, rock pools & Price \& John (1980) \\
\hline $\begin{array}{l}\text { Sphacelaria rigidula Kützing }=\text { Sphacelaria furcigera Kützing } \\
\text { RHODOPHYTA }\end{array}$ & 6 & Sublittoral rocks, substratum culture & Price \& John (1980) \\
\hline Acanthophora muscoides (Linnaeus) Bory de Saint-Vincent ${ }^{\mathrm{b}}$ & & & John et al. (2004) \\
\hline Acanthophora ramulosa Lindenberg ex Kützing & 3 & Beach rock & \\
\hline
\end{tabular}


Table 1. Continued

\begin{tabular}{|c|c|c|c|}
\hline & $\begin{array}{l}\text { Location } \\
\text { found }\end{array}$ & Habitat & Previous records \\
\hline Acrochaetium microscopicum (Nägeli ex Kützing) Nägeli & 3,13 & Epiphyte on various macroalgae & \\
\hline Aglaothamnion sp. & 4 & Sublittoral rocks & \\
\hline Ahnfeltia plicata (Hudson) E.M. Fries & 3 & Beach rock & John et al. (2004) \\
\hline Amphiroa fragilissima (Linnaeus) J.V. Lamouroux & & & Price \& John (1980) \\
\hline Amphiroa rigida J.V. Lamouroux & 1 & Rock pools & Price \& John (1979) \\
\hline Asparagopsis taxiformis (Delile) Trevisan de Saint-Léon ${ }^{c}$ & $3,6,13$ & Rock pools, sublittoral rocks & \\
\hline $\begin{array}{l}\text { Bostrychia intricata (Bory de Saint-Vincent) Montagne }= \\
\quad \text { Bostrychia mixta J.D. Hooker \& Harvey }\end{array}$ & & & John et al. (2004) \\
\hline Catenella caespitosa (Withering) L.M. Irvine & & & John et al. (2004) \\
\hline Centroceras clavulatum (C. Agardh) Montagne ${ }^{\mathrm{d}}$ & & & Price \& John (1980) \\
\hline Centroceras gasparrinii (Meneghini) Kützing & 3,6 & Rock pools, sublittoral rocks & \\
\hline $\begin{array}{l}\text { Ceramium cimbricum H.E. Petersen cf. cimbricum = Ceramium } \\
\text { fastigiatum Harvey }\end{array}$ & & & Price \& John (1980) \\
\hline Ceramium cimbricum cf. flaccidum (H.E. Petersen) Furnari \& Serio & 5 & Sublittoral rocks & \\
\hline $\begin{array}{l}\text { Ceramium diaphanum (Lightfoot) Roth = Ceramium gracillimum } \\
\text { (Kützing) Zanardini = Ceramium tenuissimum (Roth) } \\
\text { Areschoug nom. illeg. }\end{array}$ & 6 & Sublittoral rocks & Price \& John (1980) \\
\hline $\begin{array}{l}\text { Ceratodictyon intricatum (C. Agardh) R.E. Norris = Gelidiopsis } \\
\text { intricata (C. Agardh) Vickers }\end{array}$ & 11 & Rock pools & Price \& John (1980) \\
\hline Champia parvula (C. Agardh) Harvey & & & John et al. (2004) \\
\hline Champia cf. puertoricensis Lozada-Troche \& D.L. Ballantine & 12 & Sublittoral rocks & \\
\hline Coelothrix irregularis (Harvey) Børgesen & & & Price \& John (1980) \\
\hline Corallophila sp. & 8,12 & Sublittoral rocks & \\
\hline Crouania attenuata (C. Agardh) J. Agardh & 4,10 & Sublittoral rocks & \\
\hline Dasya ocellata (Grateloup) Harvey & 4 & Sublittoral rocks & \\
\hline Dasya rigidula (Kützing) Ardissone & 4 & Sublittoral rocks & \\
\hline Digenea simplex (Wulfen) C. Agardh & & & Price \& John (1979) \\
\hline Diplothamnion tetrastichum A.B. Joly \& Yamaguishi & & & Price \& John (1980) \\
\hline Erythrotrichia bertholdii Batters & 3 & Epiphyte on various macroalgae & \\
\hline Erythrotrichia carnea (Dillwyn) J. Agardh & $4,6,7$ & Epiphyte on various macroalgae & John et al. (2004) \\
\hline Galaxaura rugosa (J.Ellis \& Solander) J.V. Lamouroux & & & John et al. (2004) \\
\hline $\begin{array}{l}\text { Gayliella flaccida (Harvey ex Kützing) T.O. Cho \& L.J. McIvor }{ }^{\mathrm{e}}= \\
\text { Ceramium flaccidum (Harvey ex Kützing) Ardissone }\end{array}$ & & & John et al. (2004) \\
\hline $\begin{array}{l}\text { Gayliella mazoyerae T.O. Cho, Fredericq \& Hommersand }= \\
\text { Ceramium gracillimum var. byssoideum (Harvey) Mazoyer }\end{array}$ & & & Price \& John (1980) \\
\hline Gayliella transversalis (F.S. Collins \& Hervey) T.O. Cho \& Fredericq & 4,6 & Sublittoral rocks & \\
\hline Gelidium pusillum (Stackhouse) Le Jolis & $1,3,4$ & Beach rock, rock pools, sublittoral rocks & Price \& John (1980) \\
\hline Griffithsia schousboei Montagne & 6 & Sublittoral rocks & \\
\hline Gymnothamnion elegans (Schousboe ex C. Agardh) J. Agardh & & & John et al. (2004) \\
\hline Halydictyon mirabile Zanardini & 12 & Sublittoral rocks & \\
\hline Herposiphonia brachyclados Pilger & 4,6 & Sublittoral rocks & Price \& John (1980) \\
\hline Herposiphonia secunda (C. Agardh) Ambronn & 6 & Sublittoral rocks & John et al. (2004) \\
\hline Herposiphonia tenella (C.Agardh) Ambronn & 9 & Rock pools & Price \& John (1980) \\
\hline $\begin{array}{l}\text { Heterosiphonia crispella (C. Agardh) M.J. Wynne = Heterosiphonia } \\
\text { wurdemannii (J. Bailey ex Harvey) Falkenberg }\end{array}$ & & & Price \& John (1980) \\
\hline Hildenbrandia rubra (Sommerfelt) Meneghini & & & Price \& John (1980) \\
\hline Hydrolithon cruciatum (Bressan) Y.M. Chamberlain & 4 & Epiphyte on macroalgae & \\
\hline $\begin{array}{l}\text { Hydrolithon farinosum (J.V. Lamouroux) D. Penrose \& Y.M. } \\
\text { Chamberlain }\end{array}$ & 4,6 & Epiphyte on macroalgae & \\
\hline Hypnea spinella (C. Agardh) Kützing & 4,12 & Sublittoral rocks & Price \& John (1980) \\
\hline Hypoglossum anomalum M.J. Wynne \& D.L. Ballantine & 4 & Sublittoral rocks & \\
\hline Hypoglossum barbatum Okamura & 6 & Sublittoral rocks & \\
\hline Jania capillacea Harvey & & & Price \& John (1980) \\
\hline Jania pumila J.V. Lamouroux & 3 & Rock pools & John et al. (2004) \\
\hline Jania rubens (Linnaeus) J.V. Lamouroux & & & Price \& John (1980) \\
\hline Laurencia brachyclados Pilger & 9 & Midlittoral rocks, rock pools & Price \& John (1980) \\
\hline Laurencia caduciramulosa Masuda \& Kawaguchi & 2 & Beach rock & \\
\hline Leptosiphonia schousboei (Thuret) Kylin & & & John et al. (2004) \\
\hline Liagora albicans J.V. Lamouroux $=$ Liagora decussata Montagne & & & Price \& John (1980) \\
\hline Liagora ceranoides J.V. Lamouroux & & & John et al. (2004) \\
\hline Lithophyllum sp. & $8,12,13$ & Sublittoral rocks & \\
\hline Lomentaria corallicola Børgesen & 6 & Sublittoral rocks & \\
\hline Lophosiphonia adhaerens Pilger & 8 & Sublittoral rocks & \\
\hline
\end{tabular}


Table 1. Continued

\begin{tabular}{|c|c|c|c|}
\hline & $\begin{array}{l}\text { Location } \\
\text { found }\end{array}$ & Habitat & Previous records \\
\hline Lophosiphonia cristata Falkenberg & & & John et al. (2004) \\
\hline Lophosiphonia obscura (C. Agardh) Falkenberg & 3 & Rock pools & \\
\hline Lophosiphonia reptabunda (Suhr) Kylin & 7 & Turtle ponds & John et al. (2004) \\
\hline Monosporus indicus Børgesen & 12 & Sublittoral rocks & \\
\hline Nitophyllum punctatum (Stackhouse) Greville & 12 & Sublittoral rocks & \\
\hline $\begin{array}{l}\text { Palisada perforata (Bory de Saint-Vincent) K.W. Nam = } \\
\quad \text { Chondrophycus papillosus (C. Agardh) D.J. Garbary \& J.T. } \\
\quad \text { Harper = Laurencia papillosa (C. Agardh) Greville }\end{array}$ & $1,3,13$ & $\begin{array}{l}\text { Blow-hole areas, midlittoral } \\
\text { rocks, beach rock, rock pools }\end{array}$ & $\begin{array}{l}\text { Price \& John (1980); } \\
\text { John et al. (2004) }\end{array}$ \\
\hline $\begin{array}{l}\text { Parviphycus setaceus (Feldmann) J. Afonso-Carrillo, M. Sanson, C. } \\
\quad \text { Sangil \& T. Diaz-Villa }\end{array}$ & 3 & Rock pools & \\
\hline Phymatolithon calcareum (Pallas) W.H. Adey \& D.L. McKibbin & & & John et al. (2004) \\
\hline Plocamium cartilagineum (Linnaeus) P.S. Dixon & & & John et al. (2004) \\
\hline Polysiphonia scopulorum Harvey & 7 & Turtle ponds & \\
\hline Polysiphonia subtilissima Montagne & 4,6 & Sublittoral rocks & Price \& John (1980) \\
\hline Rhodymenia holmesii Ardissone & & & John et al. (2004) \\
\hline Rhodymenia sp. & 10 & Sublittoral rocks & \\
\hline Sahlingia subintegra (Rosenvinge) Kornmann & 4,7 & $\begin{array}{l}\text { Epiphyte on Cladophora } \\
\text { hutchinsiae and Bryopsis spp. }\end{array}$ & \\
\hline Spyridia filamentosa (Wulfen) Harvey & & & John et al. (2004) \\
\hline $\begin{array}{l}\text { Stylonema alsidii (Zanardini) K.M. Drew = Goniotrichum alsidii } \\
\quad \text { (Zanardini) M.A. Howe }\end{array}$ & 4 & Sublittoral rocks, substratum culture & John et al. (2004) \\
\hline Tiffaniella gorgonea (Montagne) Doty \& Meñez & 1 & Epiphyte on Codium taylorii & \\
\hline Vickersia baccata (J. Agardh) Karsakoff & 6,13 & Sublittoral rocks & \\
\hline Wrangelia argus (Montagne) Montagne & 4,14 & Sublittoral rocks & Price \& John (1980) \\
\hline
\end{tabular}

a, originally described from Ascension Island as Fucus lendigerum Linnaeus (1753), based on drift material collected by Osbeck (1757, 1765, 1771). However, neither the following phycologists visiting the island nor we have managed to detect the species, and we cite this species as taxon inquirendum; b , based on Perrone et al. (2006), this species should be treated as taxon inquirendum, since its neotype and other herbarium specimens studied probably correspond to different species; ${ }^{\mathrm{c}}$, only the tetrasporophytic stage found: Falkenbergia hillebrandii (Bornet) Falkenberg; ${ }^{\mathrm{d}}$, according to Won et al. (2009) specimens identified using the 'traditional' concept for Centroceras clavulatum usually fall into other species. The actual C. clavulatum is restricted to the Pacific Ocean and thus the Price \& John (1980) record probably corresponds to another species of the genus, possibly C. gasparrinii; ${ }^{\text {e }}$, according to the phylogenetic study by Cho et al. (2008) the 'Ceramium flaccidum' complex accommodates several Gayliella species. Thus, the single record of C. flaccidum by John et al. (2004) requires further investigation.

an Olympus PTWC-01 camera with PTDP-EPo5 housing. The material collected was preserved in $4 \%$ buffered formalin/seawater and/or mounted on Bristol paper, pressed, air dried and prepared as herbarium specimens and silica-gel samples.

Specimens were studied in the laboratory of the Ascension Conservation Centre, under dissecting or compound microscopes. When necessary, they were sectioned manually with a razor blade. Species were identified down to the lowest possible taxonomic level. In several cases permanent material was prepared as microscope slides using Karo ${ }^{\mathrm{TM}}$ corn syrup $(\mathrm{ACH}$ Food Companies, Memphis, TN, USA).

Herbarium specimens have been deposited in the herbarium at the University of Aberdeen (School of Biological Sciences). For present-day taxonomic and nomenclatural opinions the following on-line taxonomic databases were consulted: Index Nominum Algarum (Silva, 2014) and AlgaeBase (Guiry \& Guiry, 2014).

Given the limited time and logistic constraints at this remote island, inevitably leading to a limited coverage of the smaller representatives of the flora, collections of seaweed specimens were supplemented by collections of substratum samples stored in sterile tubes during the survey dives. Following return to Europe and based upon a protocol developed for a similar study in the Juan Fernandez Islands (Müller \& Ramirez, 1994), these samples were incubated in Provasoli- enriched seawater (Starr \& Zeikus, 1993) under white fluorescent light ( $12 \mathrm{~h}$ day: $12 \mathrm{~h}$ night) and a temperature of $18^{\circ} \mathrm{C}$, which is slightly below the lower limit of the sea surface temperature present around Ascension. Over the next roughly three months, they were monitored for algal outgrowth, from which uni-algal isolates were made. Isolates were characterized and identified morphologically using a Zeiss PrimoVert inverted microscope and a Zeiss Axio Imager.D2 compound microscope, and by DNA sequencing and comparison with published data. The isolates have been deposited in the Culture Collection of Algae and Protozoa (CCAP, Oban).

DNA extractions were performed on four of the cultured isolates using CTAB buffer as described previously (Gachon et al., 2009), or by using the GeneJET plant DNA kit (ThermoScientific; Cat. No. Ko791) and following the manufacturer's instructions. Polymerase chain reactions (PCRs) were performed using specific primers for the internal transcribed spacer (ITS) and the small subunit rDNA (SSU). For ITS amplification, the primer pairs PI (Tai et al., 2001) and KIRI (Lane et al., 2006), or ITS 1 and ITS 4 (White et al., 1990) were used. SSU fragment amplification was achieved using the primer pair $\mathrm{NS}_{1}$ and $\mathrm{NS}_{4}$ (White et al., 1990). Table 2 gives details of the primer sequences and some of the PCR conditions used. PCR was carried out with an initial denaturation at $94^{\circ} \mathrm{C}$ for $5 \mathrm{~min}$, followed by 40 cycles of amplification consisting of denaturation at $94^{\circ} \mathrm{C}$ for $30 \mathrm{~s}$, 
then annealing and extension steps as shown in Table 2. The 40 cycles were followed by a final extension at $72^{\circ} \mathrm{C}$ for $5 \mathrm{~min}$. PCR amplification was performed using BIOTAQ ${ }^{\mathrm{TM}}$ DNA Polymerase ( 5 units $\mu \mathrm{l}^{-1}$; Bioline) and following the manufacturer's instructions while incorporating $1 \mu \mathrm{l}$ of template DNA. PCR products were electrophoresed on $1.2 \%(\mathrm{w} / \mathrm{v})$ agarose gels which were stained in GelRed nucleic acid stain and resulting DNA bands were visualized using a gel imager. Products of interest were sequenced by sending samples to either MWG Eurofins or Source Bioscience.

The alignment of each DNA sequence returned was conducted using the BioEdit Sequence Alignment Editor ${ }^{\mathrm{TM}}$ (Hall, 1999). For identifying taxa, sequences were compared to published data by means of NCBI BLAST searches (Altschul et al., 1997).

\section{RESULTS}

In total, 82 marine macroalgae in species and infraspecific level were identified from our samplings (Table 1): 18 green algae (Ulvophyceae); 15 brown algae (Phaeophyceae); and 49 red algae (Rhodophyta). In addition, four taxa belonging to the genera Aglaothamnion, Corallophila, Lithophyllum and Rhodymenia were given under their generic names as identification to species level would require collection of fertile material and none of the material collected contained reproductive structures.

Among our results, 38 species and infraspecific taxa are reported for the first time from Ascension Island: seven green, three brown and 28 red macroalgae, raising the total number of seaweeds recorded in Ascension so far to 112 taxa in species and infraspecific level (Table 1).

Culturing substratum samples and monitoring algal outgrowth resulted in the isolation of four algal species which were further characterized by sequencing their partial SSU-ITS genes (Table 3). Two of them were confirmed (by both morphological identification and sequence homologies) to be Ulvella leptochaete and Stylonema alsidii respectively, of which $U$. leptochaete was not detected in our field samplings. Sphacelaria rigidula was identified morphologically (based on the presence of propagules) with a closest SSU sequence homology with Sphacelaria sp. UTEX LB8oo. Finally, some ambiguity remains about the Ulva isolate (Table 3). Based on classical taxonomy it was close to U. clathrata but the SSU was $99 \%$ similar to $U$. pertusa and $U$. lactuca. For ITS, however, the best BLAST hits (90\% identity) were U. prolifera, U. erecta, U. taeniata, Ulva sp., and the two public sequences of $U$. clathrata showed only 88 and $87 \%$ identity. The identity of our isolate will have to be resolved in the context of currently ongoing taxonomic revisions of this genus.

\section{DISCUSSIDN}

\section{Floristics}

Seventy-four species and infraspecific taxa had already been reported from Ascension Island in previous studies (Lawson \& Price, 1969; Price et al., 1978, 1986, 1988, 1992; John et al., 1979, 1994, 2004; Price \& John, 1979, 1980; Lawson et al., 1995; Woelkerling et al., 1998). Based on our collections, 38 species and infraspecific taxa are added to the Ascension seaweed flora, raising the total number of recorded seaweeds so far to 112 taxa. As a result, the benthic flora of Ascension Island is richer than that of neighbouring St Helena, where only 47 species are known (Bolton et al., 2003). However, this difference may reflect the fewer studies conducted in St Helena regarding seaweeds.

Among our new records, rare species of interest include the green alga Cladophora corallicola and the red algae Acanthophora ramulosa, Champia cf. puertoricensis, Lophosiphonia adhaerens and Laurencia caduciramulosa. The latter might correspond to a recent introduction to Ascension Island, since it was reported only recently from the Atlantic Ocean: Brazil, Cuba and the Canary Islands (Cassano et al., 2008; Senties et al., 2010).

Our new records of Erythrotrichia bertholdii, Hydrolithon cruciatum and Vickersia baccata for Ascension, all known from the north-east and subtropical Atlantic Ocean and the Mediterranean Sea (Tsiamis et al., 2011; Guiry \& Guiry, 2014) extend their distribution range to the tropical Atlantic Ocean. However, the vast majority of the recorded Ascension seaweeds are common in the tropical Atlantic Ocean. The algal flora of Ascension Island has features in common with those of both the eastern and western parts of the tropical and subtropical Atlantic Ocean (John et al., 2004; Wynne, 2011). Only a few species occurring in Ascension Island are absent from the western tropical and subtropical Atlantic Ocean, such as the red algae Herposiphonia brachyclados, Laurencia brachyclados, Lophosiphonia adhaerens and Rhodymenia holmesii. On the other hand, some red algae found in Ascension, such as Champia cf. puertoricensis, Diplothamnion tetrastichum, Lomentaria corallicola and Monosporus indicus, are lacking from the western coasts of Africa.

Most of the algal species were encountered on sublittoral rocks, holes and crevices or in rock pools. A number of 31 taxa $(36 \%$ of our collections) were found exclusively in the

Table 2. Sequences of primers used in polymerase chain reaction (PCR) for the amplification of partial nuclear ribosomal internal transcribed spacer and small subunit rDNA genes of 4 algal isolates (Table 3 ) from Ascension Island. Also detailed are the annealing and extension steps, along with the expected PCR product size.

\begin{tabular}{|c|c|c|c|c|}
\hline Primer sequences $\left(5^{\prime} \rightarrow 3^{\prime}\right)$ & Annealing & Extension & Product size & Reference \\
\hline ITSP1: GGAAGGAGAAGTCGTAACAAGG & $45^{\circ} \mathrm{C}$ for $30 \mathrm{~s}$ & $72^{\circ} \mathrm{C}$ for $1 \mathrm{~min}$ & $\sim 500 \mathrm{bp}$ & Tai et al. (2001) \\
\hline ITSK1R1: TTCAAAGTTTTGATGATT & & & & Lane et al. (2006) \\
\hline ITS1: TCCGTAGGTGAACCTGCGG & $55^{\circ} \mathrm{C}$ for $30 \mathrm{~s}$ & $72^{\circ} \mathrm{C} 1 \mathrm{~min} 30 \mathrm{~s}$ & Variable bp & White et al. (1990) \\
\hline ITS4: TCCTCCGCTTATTGATATGC & & & & White et al. (1990) \\
\hline NS1: GTAGTCATATGCTTGTCTC & $55^{\circ} \mathrm{C}$ for $30 \mathrm{~s}$ & $72^{\circ} \mathrm{C} 1 \mathrm{~min} 30 \mathrm{~s}$ & $\sim 1250 \mathrm{bp}$ & White et al. (1990) \\
\hline NS4: CTTCCGTCAATTCCTTTAAG & & & & White et al. (1990) \\
\hline
\end{tabular}


sublittoral zone, pointing out the importance of carrying out SCUBA diving-based collections in poorly explored areas.

The present study attempted to complement the findings of field-collected samples by culturing portions of substratum collected during dives followed by identification of any isolates obtained by means of light microscopes and molecular analyses. Some success was achieved since one of the four taxa isolated (Ulvella leptochaete) was not discovered in field-collected samples and was identified based on morphological and molecular analysis (Table 3 ). This approach has proven particularly rewarding in remote locations where time in the field and local laboratory facilities may be limited, for example in the Juan Fernandez Islands (Müller \& Ramirez, 1994). Besides the green algae Ulva clathrata and Ulvella leptochaete, the red alga Stylonema alsidii and the brown alga Sphacelaria rigidula, we have generated numerous isolates of small multicellular algae whose identification is underway.

\section{Overall marine vegetation}

The marine vegetation around Ascension Island seems unchanged since the Price \& John $(1979,1980)$ visit in 1976. As pointed out by the latter authors, sublittoral marine vegetation seems absent at first sight. Seagrasses do not exist, probably due to strong wave exposure occurring on the sandy beaches. When it comes to the rocky bottom, the only evident dominant seaweeds covering the sublittoral seafloor are the non-geniculate coralline red algae, which seem to remain tolerant to heavy grazing by the blackfish that prevail around Ascension. These corallines cover large surfaces and constitute crucial structuring elements to the seabed communities and dominate the underwater seascape (see also Price \& John, 1979, 1980). They either form towerlike, reef-forming structures or loose piles on the seabed (maerl-rhodoliths). Most of them correspond probably to Lithophyllum species (Athanasios Athanasiadis, personal communication) and further investigations are underway to identify the crustose coralline algae at species-level. Finally, conspicuous cyanobacteria can be found growing on coralline formations, which apparently are not grazed by the blackfish.

However, a closer look around Ascension's sublittoral shores reveals the presence of inconspicuous non-coralline seaweeds (see Table 1), with diminutive and repent habit creating turf-like mats, an adaptation to the strong grazing pressure by the blackfish, while in crevices, where access for the blackfish is limited, more flourishing algal communities can be encountered, such as Padina gymnospora and Cladophora spp.

Far more luxuriant and extensive seaweed populations can be found in shallower waters, where access for the blackfish is restricted. Midlittoral rocks and beach rocks, rock pools (including the turtle pond), blow-hole areas and the outfall channel host the most abundant and diverse seaweed clumps in the island, as noted also by Price \& John (1979, 1980), including various seaweeds such as Chaetomorpha antennina, Codium taylorii, Asteronema breviarticulatum, Chnoospora minima, Colpomenia sinuosa, Levringia brasiliensis, Palisada perforata and many others (see Table 1).

Finally, marine vegetation surveys did not reveal any major differences between the two samplings seasons (September and February), possibly due to the small seasonal variation in sea temperature: $23-25^{\circ} \mathrm{C}$ water temperature during the cold season and up to $28^{\circ} \mathrm{C}$ during the warm season 
(Shallow Marine Surveys Group, Stanley, Falkland Islands, unpublished personal communication).

\section{CONCLUSION}

Our knowledge about the marine algal flora of Ascension is increased by the addition of 38 species and infraspecific taxa as a result of the present study, and the number of taxa now recorded for the island is 112. Still, there is no doubt that this number is an underestimation, since most parts of the island, and also, in particular the deeper parts of the euphotic benthos, remain unexplored. Therefore, additional surveys are crucial for further exploration of the marine benthic flora of Ascension.

\section{ACKNDWLEDGEMENTS}

We are grateful to Nick John, Jimmy Young and Caroline Yon (all in Ascension Island) for sampling assistance. We would also like to thank Konstantinos Kondylis for help with the DNA amplification of macroalgal isolates. We are grateful to the Shallow Marine Surveys Group and the South Atlantic Environmental Research Institute for organizing the expedition. We are also very grateful to the Ascension Island Government, the members of staff at the Conservation Centre and Ascension Island Dive Club for their cooperation, accommodation and hospitality. Finally we are grateful to British Forces South Atlantic Islands for their logistic support.

\section{FINANCIAL SUPPDRT}

The MASTS pooling initiative (Marine Alliance for Science and Technology for Scotland, funded by the Scottish Funding Council and contributing institutions; grant reference HRo9011) is gratefully acknowledged for supporting F.C.K. The funding for this work came from a grant to the Shallow Marine Surveys Group from the Darwin Initiative (EIDCFo12).

\section{REFERENCES}

Altschul S.F., Madden T.L., Schäffer A.A., Zhang J., Zhang Z., Miller W. and Lipman D. J. (1997) Gapped BLAST and PSI-BLAST: a new generation of protein database search programs. Nucleic Acids Research 25, 3389-3402.

Askenasy E. (1888) Algen mit Unterstützung der Herren E. Bornet, E. Grunow, P. Hariot, M. Moebius, O. Nordstedt bearbeitet. In Engler A. (ed.) Forschungsreise S.M.S. 'Gazelle' Theil 4 Botanik. Berlin, E.S. Mittler \& Sohn, pp. 1-58.

Bolton J.J., De Clerck O. and John D.M. (2003) Seaweed diversity patterns in Sub-Saharan Africa. In Decker C., Griffiths C.L., Prochazka K., Ras C. and Whitfield A. (eds) Proccedings of the Marine Biodiversity in Sub-Saharan Africa: the known and the unknown. Cape Town, South Africa, 23-26 September 2003, pp. 229-241.

Bory de Saint-Vincent J.B.G.M. (1829) Cryptogamie. In Duperrey L.I. (ed.) Voyage autour du monde, exécuté par ordre du Roi, sur la corvette de sa majesté, La Coquille, pendant les années 1822, 1823, 1824 et 1825. Paris: Bertrand, pp. 201-301.
Cassano V., Gil-Rodríguez M.C., Sentíes A. and Fujii M.T. (2008) Laurencia caduciramulosa (Ceramiales, Rhotophyta) from the Canary Islands, Spain: a new record for the eastern Atlantic Ocean. Botanica Marina 51, 156-158.

Chace F.A. Jr and Manning R.B. (1972) Two new caridean shrimps, one representing a new family, from marine pools on Ascension Island (Crustacea: Decapoda: Natantia). Smithsonian Contributions to Zoology 131, 1-18

Cho T.O., Boo S.M., Hommersand M.H., Maggs C.A., McIvor L.J. and Fredericq S. (2008) Gayliella gen. nov. in the tribe Ceramieae (Ceramiaceae, Rhodophyta) based on molecular and morphological evidence. Journal of Phycology 44, 721-738.

Gachon C.M.M., Strittmatter M., Müller D.G., Kleinteich J. and Küpper F.C. (2009) Detection of differential host susceptibility to the marine oomycete pathogen Eurychasma dicksonii by real-time PCR: not all algae are equal. Applied and Environmental Microbiology 75, 322-328.

Guiry M.D. and Guiry G.M. (2014) AlgaeBase. Galway: National University of Ireland. Available at: http://www.algaebase.org (accessed 28 June 2014).

Hall T.A. (1999) BioEdit: a user-friendly biological sequence alignment editor and analysis program for Windows 95/98/NT. Nucleic Acids Symposium Series 41, 95-98.

John D.M., Lawson G.W., Price J.H., Prud'homme van Reine W.F. and Woelkerling W.J. (1994) Seaweeds of the western coast of tropical Africa and adjacent islands: a critical assessment. IV. Rhodophyta (Florideae) 4. Genera L-O. Bulletin of the British Museum (Natural History) Botany 24, 49-90.

John D.M., Price J.H., Maggs C.A. and Lawson G.W. (1979) Seaweeds of the western coast of tropical Africa and adjacent islands: a critical assessment. III. Rhodophyta (Bangiophyceae). Bulletin of the British Museum (Natural History) Botany 7, 69-82.

John D.M., Prud'homme van Reine W.F., Lawson G.W., Kostermans T.B. and Price J.H. (2004) A taxonomic and geographical catalogue of the seaweeds of the western coast of Africa and adjacent islands. Beihefte zur Nova Hedwigia 127, 1-339.

Lane C.E., Mayes C., Druehl L.D. and Saunders G.W. (2006) A multigene molecular investigation of the kelp (Laminariales, Phaeophyceae) supports substantial taxonomic re-organization. Journal of Phycology 42, 493-512.

Lawson G.W. and Price J.H. (1969) Seaweeds of the western coast of tropical Africa and adjacent islands: a critical assessment. I. Chlorophyta and Xanthophyta. Journal of the Linnean Society of London, Botany 62, 279-346.

Lawson G.W., Woelkerling W.J., Price J.H., Prud'homme van Reine W.F. and John D.M. (1995) Seaweeds of the western coast of tropical Africa and adjacent islands: a critical assessment. IV. Rhodophyta (Florideae) 5. Genera P. Bulletin of the British Museum (Natural History), Botany 25, 99-122.

Linnaeus C. (1753) Species plantarum, exhibentes plantas rite cognitas, ad genera relatas, cum differentiis specificis, nominibus trivialibus, synonymis selectis, locis natalibus, secundum systema sexuale digestas. Stockholm: Impensis Laurentii Salvii. Vol Holmiae.

Müller D.G. and Ramirez M.E. (1994) Filamentous brown algae from the Juan Fernandez Archipelago (Chile): contribution of laboratory culture techniques to a phytogeographic survey. Botanica Marina 37 , 205-211.

Osbeck P. (1757) Dagbok öfwer en Ostindisk resa åren 1750, 1751, 1752. Med anmårkningar uti naturkunnigheten, fråmmande folkslags språk, seder, hushållning. Stockholm: Tryckt hos L.L. Grefing. 
Osbeck P. (1765) In Koppe J.C. (ed.) Reise nach Ostindien und China Nebst O. Toreens Reise nach Suratte und C.G. Ekebergs Nachrich von der Landwirthschaft der Chineser. Aus dem Schwedischen übersetzt von J.G. Georgi. Johann Christian Koppe, Rostock, pp. 552.

Osbeck P. (1771) In White B (ed.) A voyage to China and the East Indies. Volume 2. Benjamin White, London, pp. 367.

Perrone C., Cecere E. and Furnari G. (2006) Growth pattern assessment in the genus Acanthophora (Rhodophyta, Ceramiales). Phycologia 45, $37-43$.

Price J.H. and John D.M. (1979) Subtidal ecology in Antigua and Ascension. Progress in Underwater Science, New Series 3, 111-133.

Price J.H. and John D.M. (1980) Ascension Island, South Atlantic: a survey of inshore benthic macroorganisms, communities and interactions. Aquatic Botany 9, 251-278.

Price J.H., John D.M. and Lawson G.W. (1978) Seaweeds of the western coast of tropical Africa and adjacent islands: a critical assessment. II Phaeophyta. Bulletin of the British Museum (Natural History) Botany 6, 87-182.

Price J.H., John D.M. and Lawson G.W. (1986) Seaweeds of the western coast of tropical Africa and adjacent islands: a critical assessment. IV. Rhodophyta (Florideae). 1. Genera A-F. Bulletin of the British Museum (Natural History) Botany 15, 1-122.

Price J.H., John D.M. and Lawson G.W. (1988) Seaweeds of the western coast of tropical Africa and adjacent islands: a critical assessment, IV. Rhodophyta (Florideae) 2. Genera G. Bulletin of the British Museum (Natural History) Botany 18, 195-273.

Price J.H., John D.M. and Lawson G.W. (1992) Seaweeds of the western coast of tropical Africa and adjacent islands: a critical assessment. IV. Rhodophyta (Florideae) 3. Genera H-K. Bulletin of the British Museum (Natural History) Botany 7, 69-82.

Senties A., Areces A., Diaz-Larrea J. and Fujii M.T. (2010) First records of Laurencia caduciramulosa and L. minuscula (Ceramiales, Rhodophyta) from the Cuban archipelago. Botanica Marina 53, $433-438$.

Silva P.C. (2014) Index Nominum Algarum. Berkeley, CA: University of California. Available at: http://ucjeps.berkeley.edu/INA.html (accessed 28 June 2014).
Starr R.C. and Zeikus J.A. (1993) UTEX-The Culture Collection of Algae at The University of Texas at Austin. The list of cultures. Journal of Phycology 29, 1-106.

Tai V., Lindstrom S.C. and Saunders G.W. (2001) Phylogeny of the Dumontiaceae (Gigartinales, Rhodophyta) and associated families based on SSU rDNA and internal transcribed spacer sequence data. Journal of Phycology 37, 184-196.

Tsiamis K., Montesanto B., Panayotidis P. and Katsaros C. (2011) Notes on new records of Ceramiales red algae from the Aegean Sea (Greece, Eastern Mediterranean). Plant Biosystems 145, 873-884.

White T.J., Bruns T., Lee S. and Taylor J. (1990) Amplification and direct sequencing of fungal ribosomal RNA genes for phylogenetics. In Innis M.A., Gelfand D.H., Sninsky J.J. and White T.J. (eds) PCR protocols: a guide to method and applications. New York: Academic Press, pp. 315-322.

Woelkerling W.J., Lawson G.W., Price J.H., John D.M. and Prud'homme van Reine W.F. (1998) Seaweeds of the western coast of tropical Africa and adjacent islands: a critical assessment. IV. Rhodophyta (Florideae) 6. Genera (Q) R-Z, and an update of current names for non-geniculate Corallinales. Bulletin of the British Museum (Natural History), Botany 28, 115-150.

Won B.Y., Cho T.O. and Fredericq S. (2009) Morphological and molecular characterization of species of the genus Centroceras (Ceramiaceae, Ceramiales), including two new species. Journal of Phycology 45 227-250.

and

Wynne M.J. (2011) A checklist of benthic marine algae of the tropical and subtropical western Atlantic: third revision. Nova Hedwigia Beihefte 140, 7-166.

\section{Correspondence should be addressed to:} F.C. Küpper Oceanlab, University of Aberdeen, Main Street, Newburgh $\mathrm{AB} 41$ 6AA, UK email: fkuepper@abdn.ac.uk 